\title{
Design, Construction and Experiment on Imbert Downdraft Gasifier Using South Sumatera Biomass and Low Rank Coal as Fuel
}

\author{
Fajri Vidian*, Hasan Basri*, Dedi Sihotang* \\ *(Mechanical Engineering Department, Universitas Sriwijaya, 30662, Inderalaya, South Sumatera, \\ Indonesia)
}

\begin{abstract}
The solid fuel must be converted to gas fuel or liquid fuel for application to internal combustion engine or gas turbine. Gasification is a technology to convert solid fuel into combustible gas. Gasification system generally consists of a gasifier, cyclone, spray tower and filter. This study is purposed to design, construction, and experiment of gasification system. The imbert downdraft gasifier was designed with $42 \mathrm{~kg} / \mathrm{h}$ for the maximum capacity of fuel consumption, $90 \mathrm{~cm}$ for height, $26.8 \mathrm{~cm}$ for main diameter and $12 \mathrm{~cm}$ for throat diameter. The gasifier was constructed from stainless steel material of SUS 304. Biomass and low rank coal from South Sumatera, Indonesia was used as fuel. The result of the experiment showed that combustible gas was produced after 15 minutes operation in average. The air fuel ratio of low rank coal was 1.7 which was higher than biomass (1.1). Combustible gas stopped producing when the fuel went down below the throat of gasifier.
\end{abstract}

Keywords: Design, Construction, Experiment, Imbert Downdraft Gasifier, Biomass, low rank coal

\section{INTRODUCTION}

Decreasing of crude oil as the energy resource will cause the need to finds the alternative of energy. The alternative of energy resource can be obtained from solid fuel. Direct utilization of solid fuel for internal combustion engine was not yet possible. The solid fuel must be converted into gas or liquid fuel. Gasification process is one of the technology that could converts solid fuel into gas fuel and has a compatible value to the crude oil [1]. Gasification process could be done on several types of gasifier. One of the most common types of gasifier is imbert downdraft as shown in Fig 1. This type of gasifier has the advantage at the low tar content in producer gas, so it can be used for internal combustion engine [2-3]. The low tar content is caused by pyrolysis gas before leaving the reactor that will be passed through the combustion zone and reduction zone (high temperature of char), so tar will be cracked into combustible gas [3-4]. Downdraft gasifier has special characteristics where the combustion zone at the center of reactor and has less diameter (throat) than the main reactor. This condition cause the gasification process more complicated. The gas production is influenced on the diameter of throat and the continuity of fuel flow down inside of the reactor especially when it passed through the throat [5-6]. Fuel continuity went down depending on the proportionality of fuel size to the throat diameter. The suitable design will help the production of combustible gas in gasification process. Some designs and experiment were done on the downdraft gasifier [7-12]. The design generally used different approach and various material constructions, therefore they would produce different characteristic of operation. Only few researchers explained the design, construction and experiment of gasification system (imbert downdraft gasifier, cyclone, spray tower, filter). This study aims to design, construction, and experiment of the imbert downdraft gasifier using South Sumatera, Indonesia biomass and low rank coal as fuel.

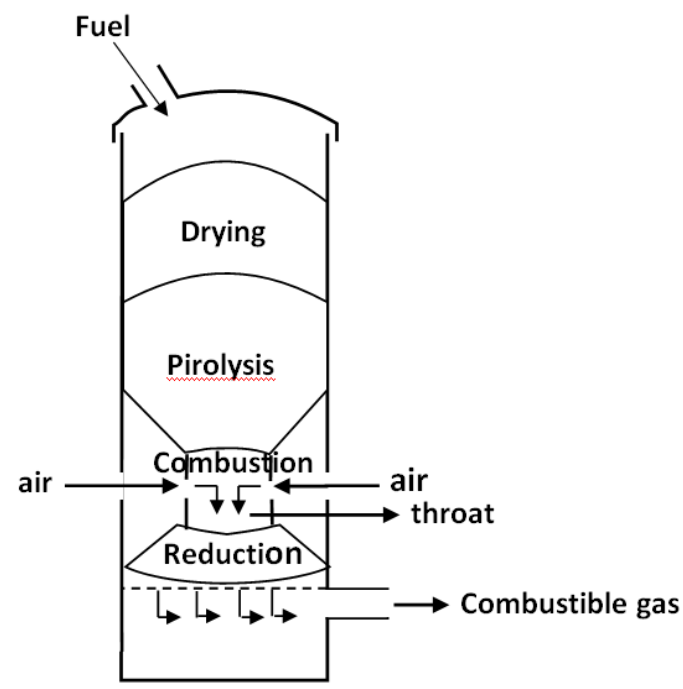

Figure 1. Imbert Downdraft Gasifier. 


\section{MATERIAL AND METHODS}

The study was started on designing of each component of gasification system then it was continued with construction or manufacturing and finally has done experiment of gasification system.

Design of the imbert downdraft gasifier, cyclone and spray tower base on principle design was reported by Reed et.al [13]. Filter was designed following approach by Ramansamy et.al [14].

The construction material of the imbert downdraft gasifier was used stainless steel SUS 304 with a thickness of $3 \mathrm{~mm}$ [15]. Cyclone was constructed by mild steel with a thickness of $2 \mathrm{~mm}$ .Spray tower and filter was made by SUS 304 with a thickness of $2 \mathrm{~mm}$. Gasifier was covered by ceramic fiber wool with $5 \mathrm{~cm}$ of thickness to ignore the heat lost to surroundings. The gasification air was supplied to the combustion zone using a suction blower with a maximum capacity of $350 \mathrm{lpm}$.

The experiment perbatch system was done using low rank coal (MT-46) and biomass (coconut sheel) from South Sumatera, Indonesia as fuel. The bulk density of fuel were $682 \mathrm{~kg} / \mathrm{m}^{3}$ for low rank coal and $397 \mathrm{~kg} / \mathrm{m}^{3}$ for biomass. Low rank coal and biomass had each of $2 \mathrm{~cm} \times 2 \mathrm{~cm} \times 1 \mathrm{~cm}$ in size and $2 \mathrm{~cm} \times 2 \mathrm{~cm} \times 2 \mathrm{~mm}$ in size as shown on Fig 2-3.

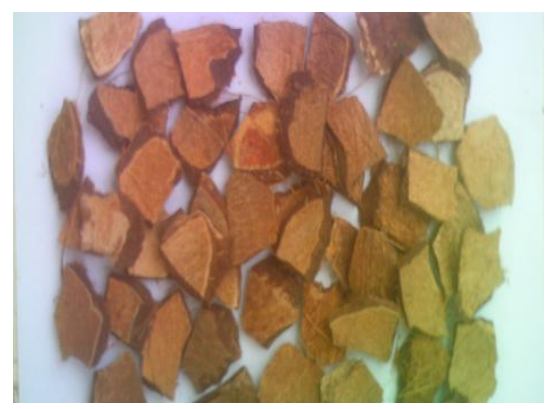

Figure 2. Biomass

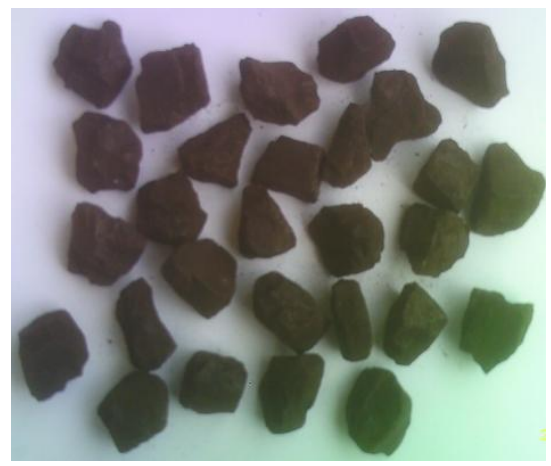

Figure 3. Low rank Coal

The amount of air stoichiometric was calculated using equation (1),
Stoikiometric of air $=\frac{1}{0,282}\left[\frac{8}{a} \mathrm{C}+8 \mathrm{H}_{2}+\mathrm{S}-\right.$

\section{$\mathrm{O}_{2}$ ] ( $\mathrm{kg}$ of air $/ \mathrm{kg}$ of fuel)}

(1)

C, $\mathrm{H}_{2}, \mathrm{~S}$ and $\mathrm{O}_{2}$ is mass fraction of each component in ultimate analysis from Table 1 and 2. The gasification air is $19 \%$ to $43 \%$ of air stoikiometric [16]. The amount of gasification air must be supplied into gasifier could be calculated using a assumption of the fuel consumption rate about 6 $\mathrm{kg} / \mathrm{h}$. The amount of gasificaton air from calculating was 6.4 to $14.4 \mathrm{~kg} / \mathrm{h}$ for biomass and 8.6 to 19.4 $\mathrm{kg} / \mathrm{h}$ for low rank coal. The actual air gasification and gas flow rate were measured using orifice flat flow meter.

Table 1. The Proximate and Ultimate of biomass

\begin{tabular}{|c|c|c|}
\hline Proximate Analysis & Unit & Value \\
\hline Moisture & Mass Fraction (\%) & 5.3 \\
\hline Ash & Mass Fraction (\%) & 6.26 \\
\hline Volatile & Mass Fraction (\%) & 70,7 \\
\hline Fixed Carbon & Mass Fraction (\%) & 17.54 \\
\hline & & \\
\hline Ultimate Analysis & & \\
\hline Carbon & Mass Fraction (\%) & 47.59 \\
\hline Hydrogen & Mass Fraction (\%) & 6.0 \\
\hline Oxygen & Mass Fraction (\%) & 45.52 \\
\hline Nitrogen & Mass Fraction (\%) & 0.22 \\
\hline Sulphur & Mass Fraction (\%) & 0.09 \\
\hline & & \\
\hline Heating Value & & \\
\hline Gross CV & kcal/kg (Adb) & 5574 \\
\hline
\end{tabular}

Table 2. The Proximate and Ultimate of Low Rank Coal

\begin{tabular}{|c|l|c|}
\hline Proximate Analysis & \multicolumn{1}{|c|}{ Unit } & Value \\
\hline Moisture & Mass Fraction & 27.79 \\
\hline Ash & Mass Fraction & 5.13 \\
\hline Volatile & Mass Fraction & 33,72 \\
\hline Fixed Carbon & Mass Fraction & 33.37 \\
\hline & & \\
\hline Ultimate Analysis & & \\
\hline Carbon & Mass Fraction & 57.35 \\
\hline Hydrogen & Mass Fraction & 4.31 \\
\hline Oxygen & Mass Fraction & 17.37 \\
\hline Nitrogen & Mass Fraction & 0.77 \\
\hline & & \\
\hline Heating Value & & \\
\hline Gross CV & kcal/kg (adb) & 5695 \\
\hline
\end{tabular}

\section{RESULT AND DISCUSSION}

\subsection{Design}

\subsubsection{Imbert Downdraft gasifier}

According to Reed et.al [14] used fuel consumption rate therefore would get the main 
dimension of gasifier. The maximum of fuel consumption of $42 \mathrm{~kg} / \mathrm{h}$ was used on design. The main dimensions of the reactor was obtained such as : diameter of gasifier (dr), diameter of throat (dh), high of the reactor from the bottom to the air inlet $(\mathrm{R}+\mathrm{H})$, high of the reactor from air inlet to the upper reactor $\left(\mathrm{H}^{\prime}\right)$, air inlet tuyer diameter $(\mathrm{dn})$ and number of air inlet tuyer (n). Five of air inlet tuyer were used to supply air gasification. All the dimension are explained in Table 3 and Fig 4.

Table 3. Dimension of Gasifier

\begin{tabular}{|l|l|l|}
\hline No & Dimension & Value \\
\hline 1 & $\mathrm{H}^{\prime}$ & 54.4 \\
\hline 2 & $\mathrm{H}$ & 25.6 \\
\hline 3 & $\mathrm{R}$ & 10 \\
\hline 4 & $\mathrm{dr}$ & 26.8 \\
\hline 5 & $\mathrm{dh}$ & 12 \\
\hline 6 & $\mathrm{dn}$ & 1.2 \\
\hline
\end{tabular}

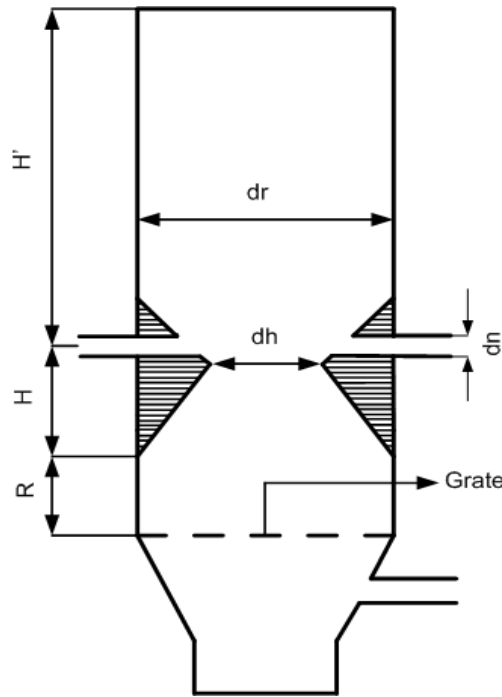

Figure 4. Imbert Downdraft Gasifier

\subsubsection{Cyclone}

The maximum of gas flow rate of 994 lpm with the gas velocity of $15 \mathrm{~m} / \mathrm{s}$ and temperature of $300{ }^{\circ} \mathrm{C}$ were designed to pass through cyclone. The main dimension of geometry of the cyclone was obtained as shown in Table 4 and Fig 5.

Table 4. Dimension of Cyclone

\begin{tabular}{|l|l|l|}
\hline No & Dimension & Value $(\mathrm{cm})$ \\
\hline 1 & Bc & 3.75 \\
\hline 2 & Dc & 15 \\
\hline 3 & Hc & 7.5 \\
\hline 4 & Lc & 30 \\
\hline 5 & Zc & 30 \\
\hline 6 & Jc & 3.75 \\
\hline 7 & Dp & 7.5 \\
\hline 8 & Qc & 10 \\
\hline
\end{tabular}

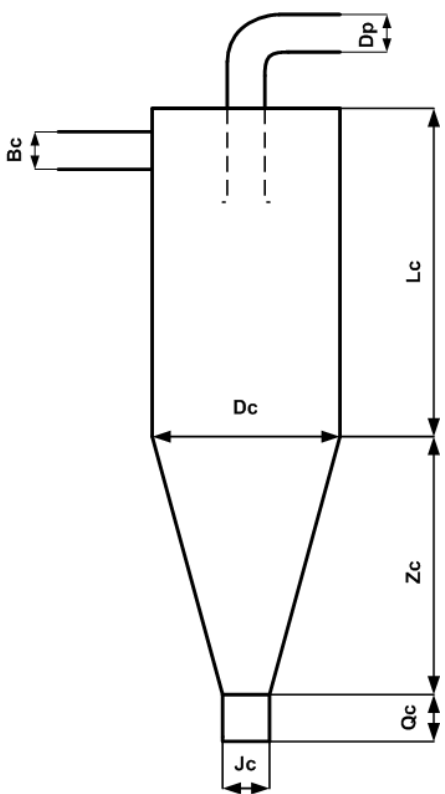

Figure 5. Cyclone

\subsubsection{Spray tower}

Spray tower was designed for the superficial gas velocity of $0.6-1.21$ and gas flow rate of $994 \mathrm{lpm}$ through the spray tower. The diameter of spray tower was obtained of $13-18 \mathrm{~cm}$. In this design, the diameter of spray tower was used of $15 \mathrm{~cm}$. The other dimension is displayed in Table 5 and Fig 6.

Table 5. Dimension of Spray Tower

\begin{tabular}{|l|l|l|}
\hline No & Dimension & Value $(\mathrm{cm})$ \\
\hline 1 & $\mathrm{H}_{1}$ & 30 \\
\hline 2 & $\mathrm{H}_{2}$ & 15 \\
\hline 3 & $\mathrm{H}_{3}$ & 15 \\
\hline 4 & $\mathrm{D}$ & 15 \\
\hline
\end{tabular}

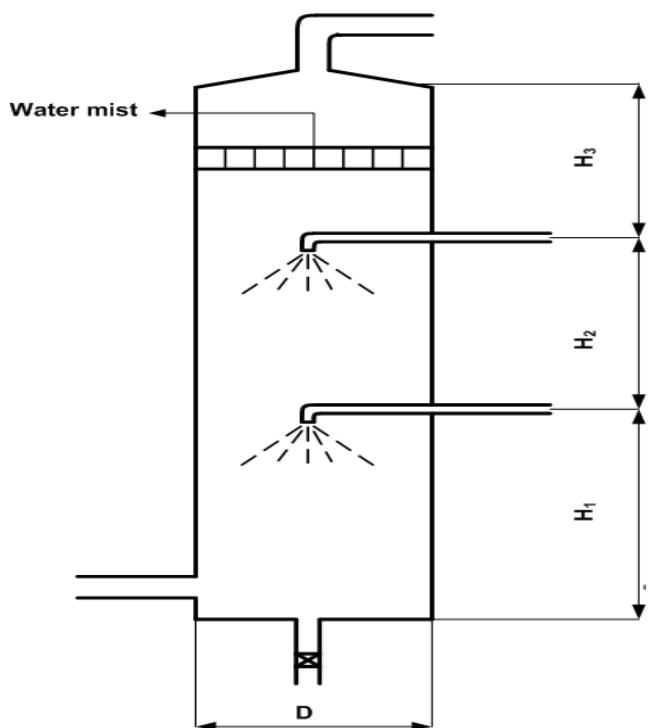

Figure 6. Spray Tower 


\subsubsection{Filter}

Filter was designed base on the retention time gas in filter of 3.5 second. The filter high $\left(h_{1}+h_{2}+h_{3}+h_{4}\right)$ was designed about $70 \mathrm{~cm}$ then the filter diameter $\left(\mathrm{D}_{\mathrm{f}}\right)$ was obtained Dimension detail is shown in Table 6 and Fig 7. Filter was constructed with two stage. the first stage was used charcoal and the second stage was used cotton as filter.

Table 6. Dimension of Filter

\begin{tabular}{|c|c|c|}
\hline No & Dimension & Value $(\mathrm{cm})$ \\
\hline 1 & $\mathrm{~h}_{1}$ & 15 \\
\hline 2 & $\mathrm{~h}_{2}$ & 20 \\
\hline 3 & $\mathrm{~h}_{3}$ & 20 \\
\hline 4 & $\mathrm{~h}_{4}$ & 15 \\
\hline 5 & $\mathrm{D}_{\mathrm{f}}$ & 32 \\
\hline
\end{tabular}

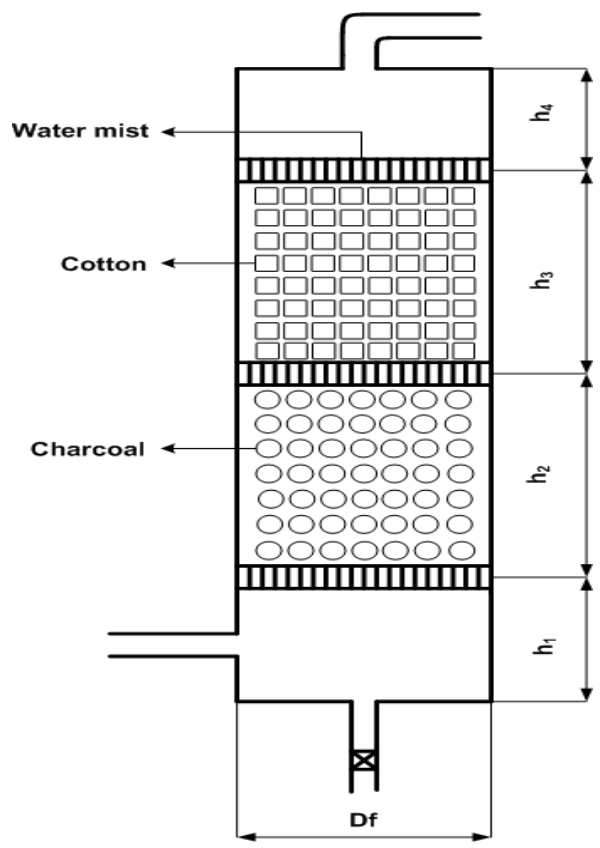

Figure 7. Filter

\subsection{Construction}

Gasification system was constructed as shown in Fig 8. The arrangement of gasification system was gasifier, cyclone, spray tower 1 , spray tower 2, filter and gas burner,

The leakage of gas testing was done to see the leakage on gasification system. The testing showed free of leakage on all of gasification component including of piping system.

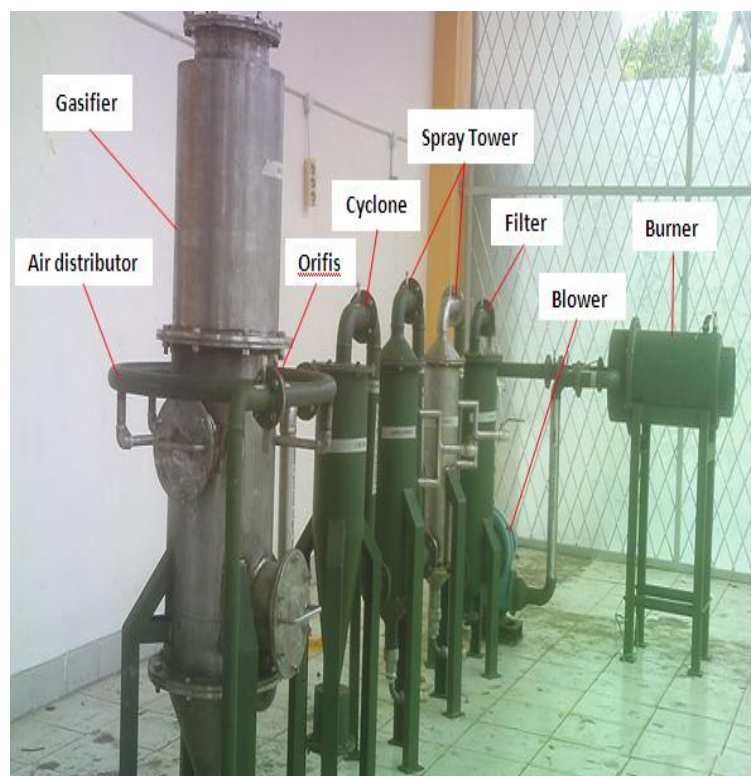

Figure 8. The Construction of Gasification System

\subsection{Experiment}

The result of experiment showed a indicating amount of fuel consumption was not the same with the predicting $(6 \mathrm{~kg} / \mathrm{h})$ as shown in Table 7. It was caused by the reactivity of the fuel influenced by many variables such as size, shape, bulk density etc. The amount of actual gasification air confirmed to predicting gasification air as shown in Table 7.

The air fuel ratio of gasification had value of 1.14 to 1.7 was not difference with reported by Lun et.al and Doghru et.al [17-18]. Combustible gas was obtained after 15 minutes of start up, it is suitable with the result was reported by Seggiani et.al and Surjosatyo et.al [19-20]. The mass flow rate of gas was approximately of $80 \%$ of total of air and fuel mass flow rate that had same trend with the result Doghru et.al and Kumararaja et.al [18,21].

The flame was produced biomass more yellow than low rank coal but low rank coal more blue as shown in Fig 9-10, due to biomass had more volatile than low rank coal as shown in Table 1-2. The air fuel ratio of low rank coal more than biomass was caused by the higher moisture content of low rank coal. The combustible gas stoped producing when the fuel position inside of the gasifier passed through the throat zone. 
Table 7. The Results of Experimental

\begin{tabular}{|l|l|l|l|l|l|}
\hline No & $\begin{array}{l}\text { Air } \\
\text { Mass } \\
\text { Flow } \\
\text { Rate } \\
(\mathrm{kg} / \mathrm{h})\end{array}$ & $\begin{array}{l}\text { Fuel } \\
\text { Mass } \\
\text { Flow } \\
\text { Rate } \\
(\mathrm{kg} / \mathrm{h})\end{array}$ & $\begin{array}{l}\text { Gas } \\
\text { Mass } \\
\text { Flow } \\
\text { Rate } \\
(\mathrm{kg} / \mathrm{h})\end{array}$ & $\begin{array}{l}\text { Air/Fuel } \\
\text { Ratio }\end{array}$ & $\begin{array}{l}\text { Duration } \\
\text { of Time } \\
\text { to get } \\
\text { combusti } \\
\text { ble gas }\end{array}$ \\
\hline \multicolumn{7}{|l|}{ Biomass } \\
\hline 1 & 7,9 & 6.9 & 11.8 & 1.14 & 10 \\
\hline 2 & 7,9 & 6,7 & 11.8 & 1.2 & 15 \\
\hline 3 & 7,9 & 6,7 & 11.8 & 1.2 & 14 \\
\hline $\begin{array}{l}\text { Aver } \\
\text { age }\end{array}$ & 7.9 & 6.8 & 11.8 & 1.16 & 13 \\
\hline Low rank coal & \multicolumn{5}{|l|}{} \\
\hline 1 & 8.5 & 5.2 & 11.8 & 1.6 & 15 \\
\hline 2 & 8.5 & 4.9 & 11.8 & 1.7 & 15 \\
\hline 3 & 8.5 & 5.0 & 11.8 & 1.7 & 16 \\
\hline $\begin{array}{l}\text { Aver } \\
\text { age }\end{array}$ & 8.5 & 5.0 & 11.8 & 1.7 & 15 \\
\hline
\end{tabular}

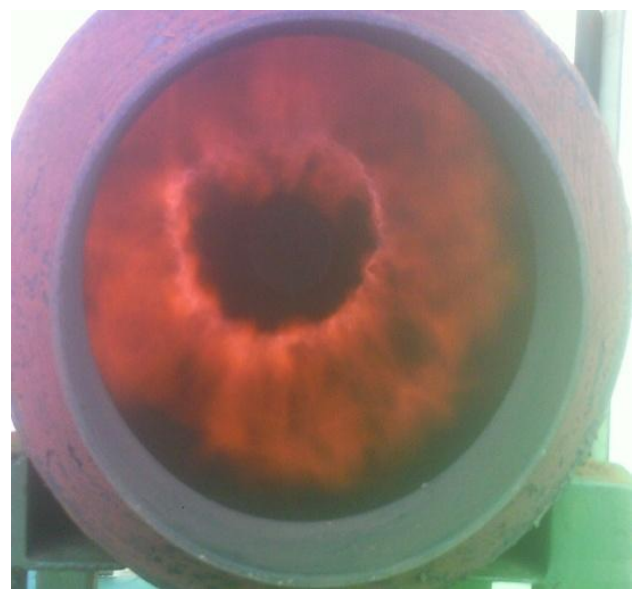

Figure 9. Biomass Flame

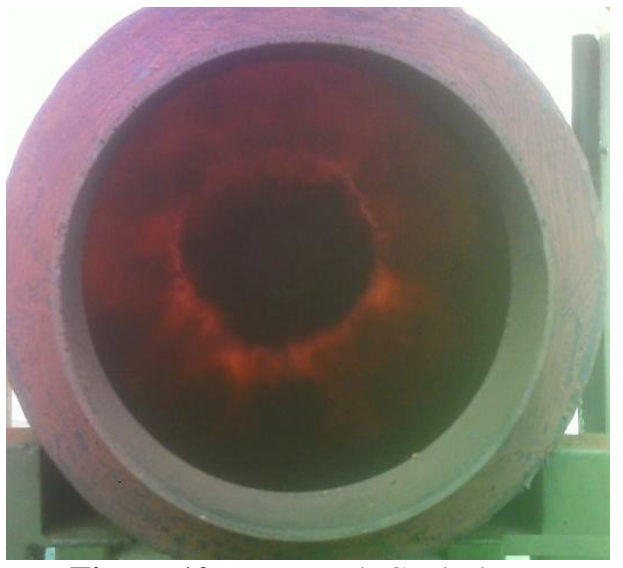

Figure 10. Low Rank Coal Flame

\section{CONCLUSION}

Gasification system consists of gasifier, cyclone, spray tower and filter that has been designed, manufactured and experimented. The system could operate properly perbatch at integrated system (gasifier + cyclone + spray tower + filter). The gasification system operated properly using biomass and low rank coal as fuel. The air fuel ratio biomass and low rank coal respectively of 1.1 and 1.7. The combustible gas was produced after 15 minutes of start up. The combustible gas stopped producing when the fuel position inside the gasifier passed through the throat zone.

\section{ACKNOWLEDGEMENTS}

The authors would like to thank the Rector of Universitas Sriwijaya for funding this research through Hibah Unggulan Kompetitip Bidang Energi 2016" under contract No 592/UN9.3.1/LT/2016. We would also like to thank to PT Tambang Batubara Bukit Asam (Persero) Tbk, Tanjung Enim, South Sumatera, Indonesia for providing low rank coal of MT-46.

\section{REFERENCES}

[1]. J.D. Martınez, E.E.S. Lora, R. V. Andrade, R.L. Jaen, Experimental study on biomass gasification in a double air stage downdraft reactor, Biomass and Bioenergy, 35, 2011, 3465-3480.

[2]. P. Donaj, M.R. Izadpanah, W. Yang, W. Blasiak, Effect of Pressure Drop Due to Grate_Bed Resistance on the Performance of a Downdraft Gasifier, Energy \& Fuel, 25 (11), 2011, 5366-5377.

[3]. J. D. Martínez, K. Mahkamov, R.V. Andrade, E.E.S. Lora, Syngas production in downdraft biomass gasifiers and its application using internal combustion engines, Renewable Energy, 38, 2012, 1-9.

[4]. Y.L. Son, S.J. Yoon, Y.K. Kim, J.G. Lee, Gasification and power generation characteristics of woody biomass utilizing a downdraft gasifier, Biomass and Bioenergy, 35, 2011, $4215-4220$.

[5]. S. Sivakumar, S. Ragunathan, N. Elango, Design and optimization analysis of $5 \mathrm{kWe}$ Downdraft Gasifier, Journal of Chemical and Pharmaceutical Sciences, 4, 2014, 141-143.

[6]. L. Montuori, S.C. Vargas, O.M. Alcázar, Impact of the throat sizing on the operating parameters in an experimental fixed bed gasifier: Analysis, evaluation and testing, Renewable Energy, 83, 2015, 615-625.

[7]. A.G. Antony, T.S. Kumar, B. Kumaragurubaran, Performance Evaluation of a down draft Gasifier using Agricultural 
Waste Biomass, International Journal of Innovative Research in Science, Engineering and Technology, 5 (5), 2016, 8659-8667.

[8]. G. Sreelal, Design, Construction \& Performance Analysis of Low Cost Fixed Bed Biomass Gasifier, ARPN Journal of Engineering and Applied Science, 10 (6), 2015, 2736-2742.

[9]. S. Sivakumar, N. Ranjithkumar, S. Ragunathan, Design and Development of Downdraft Wood Gasifier, International Journal of Mechanical Engineering (IJME), $l$ 2 (2), 2013, 1-10.

[10]. M.A. Chawdhury, K. Mahkamov, Development of a Small Downdraft Biomass Gasifier for Developing Countries, Journal of Scientific Research, 3(1), 2011, 51-64.

[11]. S.P. Moharkar, P.D. Padole, Design and Development of Downdraft Gasifier for Rural Area", International Conference on Emerging Frontiers in Technology for Rural Area (EFITRA) Proceedings published in International Journal of Computer Applications (IJCA), 2012,24-26.

[12]. H. Olgun, S. Ozdogon, G. Yinesor, Resulth With A Bench Scale Downdraft Biomass Gasifier for Agricultural and Forestry Residues, Biomass \& Bioenergy, 35, 2011, 572-580.

[13]. T. B. Reed, A. Das, Handbook of Biomass Downdraft Gasifier Engine Systems (Solar Energy Research Institute, 1988)

[14]. R. Ramansamy, M.K. Gounder, A Novel Hybrid Compact Filter System for A Downdraft Gasifier : An Experimental Study, Journal of Scientific \& Industrial Research, Vol 72, 2013, 663-668.

[15]. Y. Ueki, T. Torigoe, H. Ono, R. Yoshiie, H.J. Kihedu, I. Naruse, Gasification Characteristic of Woody Biomass in The Packed Bed Reactor, Proceedings of The Combustion Institute, 33, 2011, 1792-1800.

[16]. ZA. Zainal, R. Ali, G. Quadir, K.N. Seetharanu, Experimental Investigation of a Downdraft Biomass Gasifier. Biomass Bioenergy, 23, 2002, 283 - 289

[17]. H.C. Lun, W.T. Yuan, T.C. Hsiung, C.C. Yuan, L.C.Hao, C.Y. Chung, J.T. Kuo, Characteristics of an Air-Blown Fixed-Bed Downdraft Biomass Gasifier, Energy Fuels, 22 (6), 2008, 4196 - 4205.

[18]. M. Dogru, C.R. Howarth, G. Akay, B. Keskinler, . A.A. Malik, Gasification of hazelnut shells in a downdraft gasifier, Energy, l27, 2002, 415-427.

[19]. M. Seggiani, S. Vittolo, M. Puccini, A.Belliani, Cogasification of Sewage Sludge in an Updraft gasifier. Fuel, 93, 2011, 486491.

[20]. A. Surjosatyo, F. Vidian, Y.S. Nugroho, Performance Gasification Perbatch Rubber Wood In Conventional Updraft Gasifier, Journal of Engineering and Applied Science, 7 (8-12), 2012, 494-500.

[21]. L. Kumararaja, P.G. Reddy, M. V. Ramanan, R.Sethumadhavan, Experimental investigation on the changes in bed properties of a downdraft biomass gasifier, International Journal of Engineering, Science and Technology, 2 (6), 2010, 98106. 